\title{
Political Constraints and Public Support for Market Reform
}

\author{
RAJ M. DESAI and ANDERS OLOFSGÅRD*
}

As concerns of "reform fatigue" in lower- and middle-income countries have become more widespread, so has the search for ways of boosting support for market-oriented reforms. Although the effects of political institutions on reform results have been extensively analyzed, there has been relatively little investigation of their effects on public opinion. We argue that constitutional and extra-constitutional reforms that place limits on the discretionary authority of public officials and enable voters to monitor, reward, and sanction politicians can enhance the legitimacy of market reforms. We present a voting model with asymmetric information to illustrate that these formal-legal reforms provide a credible signal of reformers' commitments. Using panel data based on public opinion barometers from Eastern Europe and Latin America, we examine the effects of political authority on public support for markets. We find that constraints on the power of the executive branch boost support for markets but that this effect declines as the reform process matures. [JEL D72, P16, P26]

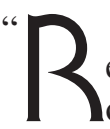
eform fatigue" in lower- and middle-income countries has become a concern of country governments, donors, and multilateral development institutions alike. There has been much recent recognition that, without legitimacy, economic reforms can erode public trust in markets-even as they may succeed in other respects (World Bank, 2004a). In this regard, many reform efforts in the 1980s

*Raj M. Desai is a Professor of International Development, and Anders Olofsgård is a Professor of Economics, at Georgetown University's Edmund A. Walsh School of Foreign Service. A previous version of this paper was presented at the IMF's Annual Research Conference in 2005. The authors thank Ashoka Mody and an anonymous reviewer for comments on an earlier draft. 
and 1990s fell short, because their outcomes were often perceived as inequitable, unjust, or otherwise inconsistent with prevailing social norms in the countries in which they were implemented. These episodes also generated backlashes against reform-oriented governments, because opposition groups from Poland to Peru discovered they could win elections by promising to repair the adverse effects of market reforms.

One of the solutions commonly sought as a means of preventing reform fatigue is "good government"-specifically, expanding political constraints on policy decisions by strengthening the legislative branch, making the civil service more transparent, improving the independence of judiciaries, and enhancing both the autonomy and responsiveness of subnational governments (see, for example, Camdessus, 1997; and Ortiz, 2003). These are the veto players in the political process-actors whose assent is required for policy decisions; they can effectively restrain the executive branch and limit the discretion of public officials. There is now general acknowledgement, moreover, of the need to pair economic reforms with reforms to political institutions (Kuczynski, 2003). This represents something of a reversal from the conventional wisdom of a decade ago, when strategists typically emphasized the need to insulate reformers from public pressures (Williamson, 1994).

We seek to understand whether reforming the institutions of the state can boost public support for market reforms. Although there have been numerous investigations into the effects of political institutions on market-oriented reform outcomes, there has been comparably little analysis of their influence on public opinioneven as the role of public opinion in shaping the success or failure of economic reforms has been accepted (see, for example, Cabanero-Vervosa and Mitchell, 2003). We begin by examining the potential ways in which economic reform can shape public opinion towards markets. In particular, we examine how the political consequences of economic reform can push public opinion in potentially opposite directions.

We then present a simple voting model with asymmetric information to illustrate the political benefits of implementing formal-legal reforms that increase the risk associated with engaging in corrupt behavior when voters are concerned about expropriation by governmental and economic elites. Here we focus primarily on restructuring the rules and procedures of government in ways that place limits on the discretionary authority of public officials and that consequently better enable voters to monitor, reward, and sanction politicians. At the core of the model is the assumption that these political-institutional reforms provide voters with credible signals of politicians' commitments to improve the welfare of all citizens. Reformers who are willing to establish constitutional and extra-constitutional mechanisms that make politicians and public officials more accountable to citizens restrict their ability to accumulate private benefits; this willingness can boost public perceptions of the legitimacy of markets. The benefits of signaling intent through these political reforms, however, diminish as the complexity of market reforms advances.

Our analysis focuses on two regions whose countries have experienced significant reforms to their market mechanisms: the post-communist "transition" countries of Eastern Europe and the Commonwealth of Independent States (CIS), 
and Latin America. Based on public opinion barometers for a sample of countries in each region, we examine the effects of changes in political constraints on public confidence in and support for markets. We find that increasing the number of veto players in government can make the public more favorably disposed toward markets, but we also find that this effect declines as the reform process matures. We find, additionally, that these relationships often vary as much within each region as they do between regions.

\section{Neo-Liberal Reform and Public Opinion}

There has been relatively little cross-national investigation of what moves public opinion during periods of pro-market reform. The conventional approach has been to assume that citizens base their opinions on how they perceive their own economic circumstances. However, this approach, which has been formalized in models of retrospective voting, has come under greater scrutiny in recent years. Empirical analyses of voting behavior in the United States and Europe, for example, have suggested that voters are as likely to be concerned with wider economic outcomes as they are with their personal welfare. Moreover, it is not clear when voters blame their governments for adverse economic conditions (Harrington, 1993; and Anderson, 1995). Finally, it is also likely that, during periods of extraordinary economic transformation, citizens interpret changes in economic conditions differently than they would under normal conditions (Stokes, 2001a). We explore below some alternative explanations of what may move public support for reform based on the principal experiences of two regions: Eastern Europe/CIS and Latin America (Figure 1).

Although the countries of Eastern Europe/CIS and Latin America initiated reforms under different circumstances, there were several commonalities between them. Countries in both regions liberalized financial markets, opened up markets to foreign investment and trade, privatized public enterprises, and deregulated markets. Moreover, reforms in both regions often occurred alongside major political transformations - namely, the end of Communist Party rule and the breakup of the U.S.S.R., or the eclipse of authoritarian rule.

Leaving aside the effects of economic performance on public opinion, citizens in these countries have also blamed market reforms for endemic corruption, political stalemate, instability, and the increased vulnerability of many segments of the population to economic deprivations. In particular, citizens in reforming economies face two types of risks that threaten to undermine support for markets-a risk of expropriation and a risk of policy fragmentation.

\section{Expropriation by Elites}

The first risk is that public officials will exploit their positions to extract private benefits at the expense of other citizens. All reforms offer numerous opportunities for arbitrage and rent seeking. In the 1990s, this came to be seen as one of the main obstacles to growth recovery - not that reforms would not be implemented but that they would be partially implemented, only to be halted by elites who prospered from arbitrage between reformed and unreformed parts of the economy and who then 
Figure 1. Average Support for Reform by Region

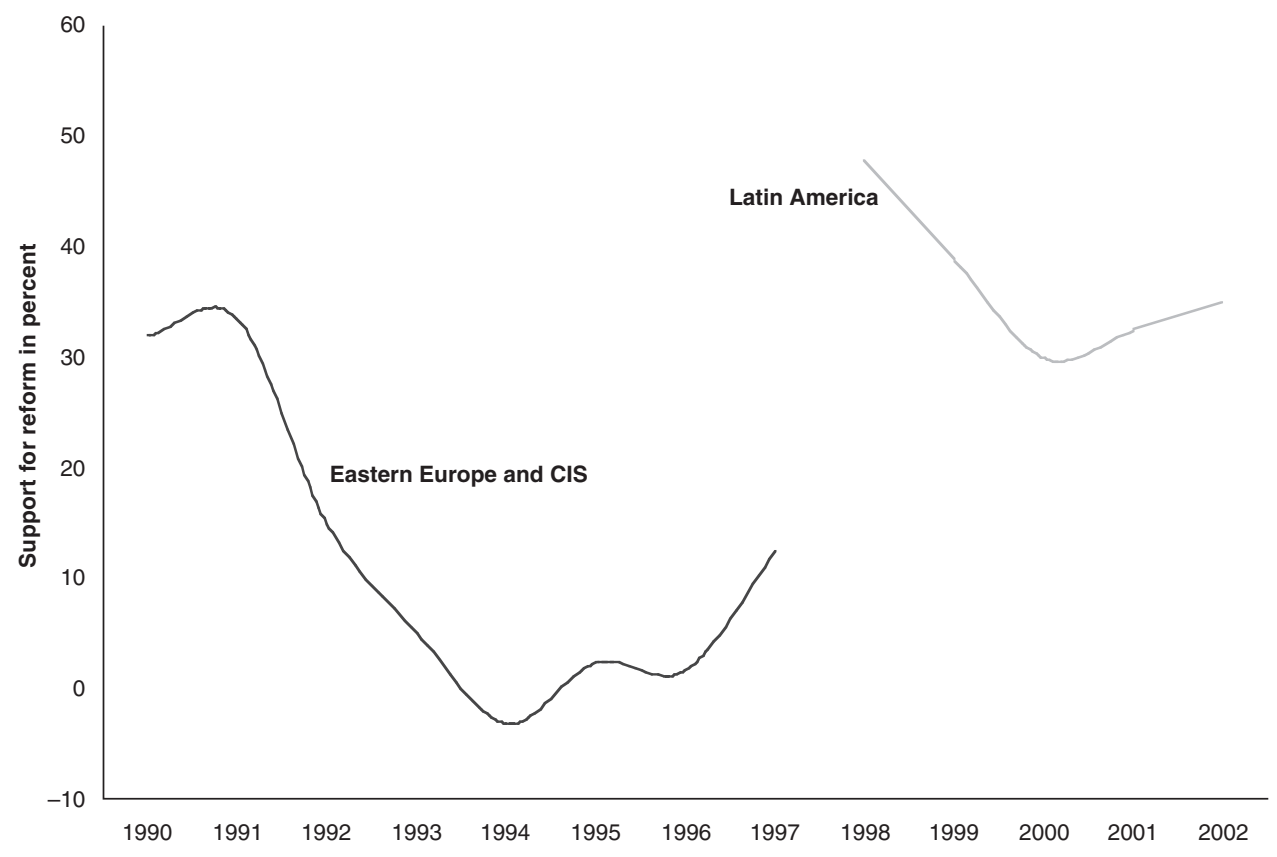

Source: Authors' calculations from data taken from Central and Eastern European Barometer and Latinobarómetro surveys.

Notes: Support for reform is the percentage that answer in the affirmative, less the percentage that answers in the negative, to a regional survey question on whether respondents believe that a market economy is in the country's best interest.

managed to "capture" legislative and policymaking institutions (Hellman, 1998). Middlemen collected large profits by importing goods at subsidized exchange rates and selling them to final producers at higher domestic prices. Mafiosi extorted protection payments where property rights and contracts were poorly enforced. In Russia and Ukraine, the "oligarchs" acquired wealth by underbidding for natural resource firms in noncompetitive auctions, by obtaining subsidized credits in specific industries, or by trading in commodities purchased domestically at regulated prices and sold abroad at deregulated prices. The typical oligarchs were former government officials who had exploited their relationships with ministries, privatization agencies, and state-owned banks to acquire wealth (see, for example, Shleifer and Treisman, 2000).

In these countries it was common for oligarchs to "buy off" legislators (in Ukraine, several oligarchs eventually became legislators) and thus control lawmaking processes (Åslund, 2000). In Central Asian nations, former high-ranking members of the Communist Party remain in control both of the apparatus of government and of the levers of the economy. Even in the states of Central Europe and the Baltics, asset-stripping by new enterprise owners threatened to undermine popular support for reform by the mid-1990s (Johnson and others, 2000). 
Inevitably, left-wing governments replaced initial reform governments in many transition countries. Two electoral outcomes, however, attest to the fact that support for reforms was undercut not by any animus toward markets but, rather, by resentments toward the newly rich or toward those who had obtained their wealth as a result of illegal activities or their status in the old regimes. First, these new governments generally continued the reform process initiated by their predecessors. Second, the Communist Parties that transformed themselves into pro-market social democratic parties tended to be better represented than those that retained their hard-line platforms or evolved into other anti-market (for example, nationalist) parties (Åslund, Boone, and Johnson, 2001). Survey data from transition countries suggest that a majority of citizens often demanded more radical reforms and that citizens in countries implementing rapid reforms were more likely to believe their countries were heading in the right direction (Warner, 2001).

Political constraints serve as a potential protection against expropriation by interlinked political and economic elites. In particular, political reforms that disperse political power beyond narrow elites should limit the ability of these groups to expropriate rents from the reform process. In sum, the establishment of additional veto points, in limiting the expropriation risk in market reforms, should boost their popularity.

\section{Policy Fragmentation}

The second risk is that political struggles between organized groups-unions, business associations, farmers, and so on-will delay vital reforms, cause them not to be implemented, or cause them to become polarized and paralyzed in the government. In Latin America, the reform eras are commonly remembered as periods of electoral volatility and of protracted struggles between fractious political parties (Corrales, 2002). Moreover, politicians' populist excesses may have led more recently to disappointments with the functioning of democratic government (Kurtz, 2004; and Lora and Olivera, 2005).

The possible side effects of fragmentation in reform processes are numerous, but all have the potential to turn public opinion away from support for economic reform and for markets in general. By many accounts, after the "lost decade" of the 1980s, many citizens came to be persuaded that the bitter pills of reform entailed both costs and benefits. Debates about these costs and benefits occupied a prominent place in critical elections (in Mexico in 1988, in Argentina and Brazil in 1989, in Chile and Peru in 1990, and in Bolivia in 1993). Although some of the winning candidates (for example, Menem in Argentina and Fujimori in Peru) may have campaigned as anti-reform, they generally accepted the need to adopt reforms that might have been opposed by some of their constituencies (Stokes, 2001b).

Reform governments, therefore, could not claim extensive mandates. Moreover, in-fighting and conflicts with opposition groups in legislatures often delayed the adoption of reform programs. Where reform programs were implemented, they were often rife with transfers and remunerations dictated by patronage. In Peru, for example, Fujimori's government poured money into public works and anti-poverty programs prior to elections (Schady, 2000). In Mexico between 1989 and 1994, the 
national poverty-alleviation program spent 1.2 percent of GDP annually on transfers heavily skewed toward municipalities dominated by the governing Institutional Revolutionary Party (Diaz-Cayeros and Magaloni, 2003). Electorally driven transfers in Latin American countries had a limited impact on actual poverty reduction; more commonly, they merely worsened countries' fiscal stances and exacerbated business cycles (Schuknecht, 2000; Gonzalez, 2002; and Mejía Reyes, 2003).

And inevitably, by the end of the 1990s, governments that had reneged on promises and that had been in power for lengthy periods began to face stronger social resistance to their policies as well as electoral punishment. As in Eastern Europe, a number of social democratic governments were elected by the end of the decade in Brazil (1998), Argentina (1999), Chile (2000), Peru (2001), and perhaps Mexico (2000). But as in the transition countries, these new governments did not abandon reform programs as much as they watered down certain components-for example, health reform or labor reform-opposed by key constituencies.

This basic idea-that political fragmentation can limit reform progress-has appeared in a number of incarnations in formal models. War-of-attrition models argue that coordination failures stem from the political advantage that groups have in "holding out" against their opponents, delaying the implementation of reforms that are in the public interest (Alesina and Drazen, 1991). Other models have suggested that coordination failures stem from uncertainty about the postreform environment (Rodrik, 1993; and Laban and Sturzenegger, 1994). In common-property models of this problem, coordination failures prompt politicians and interest groups to deplete stocks of assets (for example, government revenues or foreignexchange-generating industries) necessary to sustain reforms (Velasco, 1997).

Although these models do not directly address the consequences for public opinion, the implication is clear: where policy fragmentation and stalemate characterize the politics of market reform programs, public opinion will sour toward economic reforms. Under these conditions, incorporating additional veto players into policymaking dialogues and procedures can exacerbate the problems of fragmentation. Meanwhile, limiting executive authority restricts the ability of the executive to circumvent stalemated legislatures. Consequently, greater political constraints, in this view, can potentially dampen public support for reforms.

\section{The Effect of Reform Maturity}

We are left, therefore, with two diametrically opposed hypotheses regarding the purported effects of enhanced political constraints on public support for market reform. According to one view, institutional limits on executive power, which restrict the ability of public officials to expropriate wealth, can increase public support for market reforms under conditions of economic uncertainty. On the other hand, checks on the authority of the central government can also delay needed reforms, worsen economic conditions, and heighten public antipathy toward markets. How can these be reconciled?

We argue that the risk of elite expropriation is greatest in the early phases of the reform process, when relationships between constituencies (supporters and opponents) and reform politicians have not yet crystallized. Reforms in the initial phases 
Figure 2. Reform and Expropriation Risk, 1990-2002

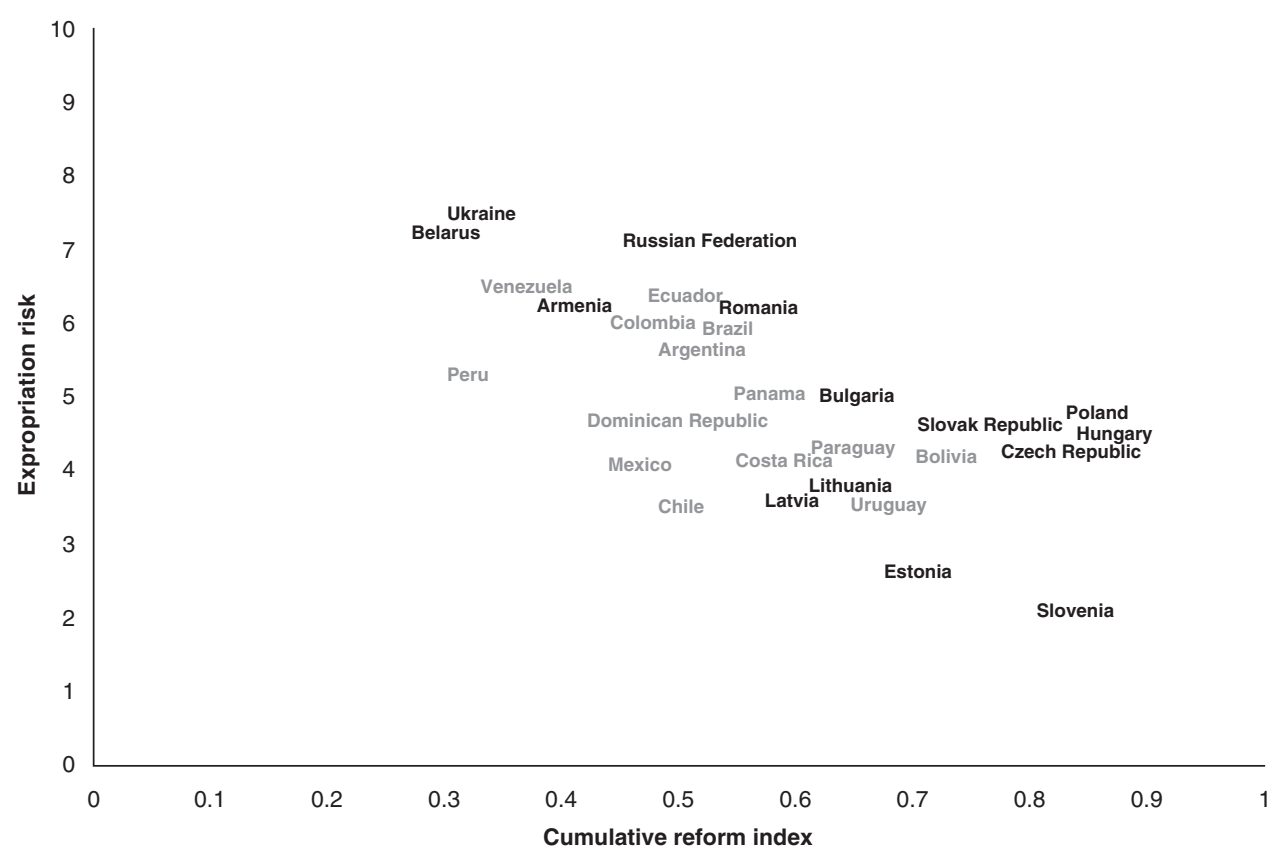

Source: Political Risk Services (2005).

Notes: Expropriation risk is taken from the "investment profile" component of the International Country Risk Guide and is rescaled such that higher scores indicate greater risk. The cumulative reform index is drawn from indices of structural reform normalized by regional maxima and minima.

are typically characterized by a lack of effective representation of group interests owing to poorly institutionalized political parties, labor unions, and business lobbies, in addition to greater uncertainty regarding the distribution of costs and benefits. Although the ability of broad-based interest groups to influence policymaking in the early stages of reform is limited, narrower elites with fewer collective-action problems and direct access to the state have few such difficulties. ${ }^{1}$ Figure 2 shows the relationship: as structural reform ensues, expropriation risk declines.

As reform programs mature, the ties between interest organizations and politicians become clearer. New policies generate their own supporters (and opponents) depending upon the resources available to different groups, who over time acquire greater access to and representation in policymaking. Indeed, "secondgeneration" reforms-reforms implemented following interest- and exchangerate adjustments, price and trade liberalization, privatization, and deregulation-are commonly thought to involve more contentious questions, as well as to require

\footnotetext{
${ }^{1}$ At the outset of the postcommunist transition, for example, group demands were generally not filtered through formal channels. Rather, smaller groups of firms - often single firms - were more likely to lobby the state directly for specific objectives (European Bank for Reconstruction and Development, 1999).
} 
more technical skill (see, for example, Naím, 1994; and Krueger, 2000). More important, the number of interests potentially affected in second-generation reforms is much larger; consequently, groups representing these interests are often far more vocal (Tommasi and Velasco, 1996).

This suggests two separate but related outcomes. First, whereas the risk of expropriation diminishes as the reform process matures, the risk of policy fragmentation increases. Second, we should expect that the effect of enhanced checks and balances on support for market reforms will be positive, provided that elite behavior is constrained, but this effect will diminish as the reform process matures. In the remainder of this paper, we formalize these views and test them against data from Eastern Europe/CIS and Latin America.

\section{A Simple Model}

We develop below a two-period voting model with two sets of players: politicians and voters. We distinguish between "committed" and "opportunistic" reformers, that is, between those reformers who are genuine and those who are willing participants in rent seeking. This information, however, is unknown to voters. In the first period, the economy faces a reform imperative owing to crises, international shocks, or other exogenous conditions. The incumbent chooses whether to implement reforms of state institutions - in particular, reforms that enhance political constraints; the choice the incumbent makes serves as a signal to voters of the incumbent's “type." A winning politician's economic policy reform agenda is implemented in the second period, following elections.

\section{Politicians}

The Period 1 incumbent is a reformer of unknown type, indistinguishable to voters, whereas the challenger is the anti-reform candidate. ${ }^{2}$ The genuine reformer will try to implement an agenda that benefits the public without collecting private benefits. Successful welfare-increasing reform will, therefore, depend on both the ability and motivation of the politician. Motivation and honesty, however, may be insufficient because reform implementation requires some ability to overcome the anti-reform opposition. Following expectations of the increasing complexity of second-generation reforms alluded to in the previous section, we will assume that later-stage reforms will be harder to implement, that is, the number and strength of anti-reform groups will grow as the reform process matures. We denote the probability of a successful reform attempt as $\delta(x)$, where $x$ indicates the maturity of the reform process and $\delta^{\prime}(x)<0$.

Both types of politicians benefit from holding office. We denote the incumbency benefits for the genuine reformer as $V$. We also assume that the total size of

2This model applies not to economies that have yet to reform but to economies that have already initiated the reform process and to economies in which reform-oriented incumbents face anti-reform challenges. If an anti-reform politician were the incumbent, reform outcomes would simply be explained by the preferences of that politician because, by definition, reform would not be on the agenda of the incumbent government. 
the elite's surplus from expropriating the reform process is $B$, and the share of that surplus paid to the opportunist as a bribe is given by $\lambda$. In addition to choosing the level of economic reform following elections, the incumbent also influences the distribution of checks and balances and thus the degree of political constraints in the political system, denoted by $\sigma \in[0,1]$. The presence of veto players is costly to any reformer because they increase the number of hurdles that politicians must overcome to make policy decisions (Tsebelis, 2002). More important, the presence of veto players also implies greater levels of monitoring by other branches and levels of government and thus increases the risk that any corrupt practices will be detected and punished. These institutional reforms, therefore, generate costs and benefits for incumbents regardless of type, ${ }^{3}$ whereas other costs accrue only to the opportunist. The optimal trade-off between the common costs and benefits is given by the specific value $\tilde{\sigma} \in[0,1]$. To capture the effect of these constraints on the punishment risk from engaging in corruption, we assume that the probability of punishment is equal to $\sigma$ and we normalize the politician's utility, if sanctioned, to zero. The expected payoff from corrupt actions for an opportunist, then, is (1 $\sigma) \lambda B$.

The utility of a committed reformer can then be formalized as

$$
-\frac{(\sigma-\tilde{\sigma})^{2}}{2}+\operatorname{Pr}(\sigma) V
$$

where $\tilde{\sigma}$ corresponds to the optimal trade-off between the costs and benefits of constraints not specific to any type of politician, and $\operatorname{Pr}(\sigma)$ is the probability of winning an election as a function of the incumbent's choice of political constraints. To increase their chances of reelection, reformers may deviate from the optimal tradeoff, $\tilde{\sigma}$, by increasing the level of political constraints. The loss from this deviation is reflected in the first term.

Following the same logic, the utility of an opportunist is

$$
-\frac{(\sigma-\tilde{\sigma})^{2}}{2}+\operatorname{Pr}(\sigma)(1-\sigma) \lambda B
$$

\section{Voters}

Voters are all identical and vote sincerely for the incumbent, or status quo candidate. Different politicians correspond to different levels of economic reform, each of which generates different levels of welfare for citizens. We denote the outcome in which the committed reformer triumphs over opposition as "reform" $(R)$, in which the opportunist assumes power as "expropriation" $(E)$, and in which the anti-reform opposition wins (or where the opposition successfully blocks the

\footnotetext{
${ }^{3}$ Benefits can take various forms, including reputational benefits for countries that improve political accountability. But there is also, of course, a personal cost to politicians for institutional reforms that allow closer scrutiny of governmental activities.
} 
reform agenda) as "reversal" $(Q){ }^{4}$ It is assumed that voters are best off with reform and worst off with expropriation, that is,

$$
u(R)>u(Q)>u(E, x)
$$

Based on the discussion above, we let utility under expropriation be a function of the maturity of the reform process, with $u_{x}^{\prime}(E, x)>0$.

Voters base their decisions on what they expect the incumbent to deliver. We refer to the prior probability that the incumbent is a committed reformer as $\alpha$, while the updated beliefs are given by $\tilde{\alpha}(\sigma)$ conditional on observing constraints $\sigma$. The incumbent's relative popularity also depends on a random variable $\varepsilon$ drawn from a distribution $G(\cdot)$ —a valence characteristic that encompasses other factors that may influence the standing of the incumbent; for example, perceived competency, charisma, or ideology. The realization of $\varepsilon$ is unknown to the incumbent, making the mapping from $\sigma$ to the electoral outcome uncertain. It follows that voters will vote for the incumbent if and only if

$$
\tilde{\alpha}(\sigma)(\delta(x) u(R)+(1-\delta(x)) u(Q))+(1-\tilde{\alpha}(\sigma)) u(E, x)-\varepsilon>u(Q)
$$

If we rearrange terms, the probability that the incumbent wins is given by the probability that

$$
\varepsilon<\tilde{\alpha}(\sigma)(\delta(x) u(R)+(1-\delta(x)) u(Q))+(1-\tilde{\alpha}(\sigma)) u(E, x)-u(Q),
$$

which can be represented as

$$
G[\tilde{\alpha}(\sigma)(\delta(x) u(R)+(1-\delta(x)) u(Q))+(1-\tilde{\alpha}(\sigma)) u(E, x)-u(Q)] .
$$

\section{Pooling and Separating Equilibria}

Based on the derivation of voting behavior, the incumbent's maximization problem can be defined as choosing $\sigma$ to maximize the following function:

$$
-\frac{(\sigma-\tilde{\sigma})^{2}}{2}+G[\tilde{\alpha}(\sigma)(\delta(x) u(R)+(1-\delta(x)) u(Q))+(1-\tilde{\alpha}(\sigma)) u(E, x)-u(Q)] \Omega
$$

where $\Omega \in\{V,(1-\sigma) \lambda B\}$. The solution to this problem depends upon how voter expectations are shaped by the incumbent's choice of $\sigma$. Expectations in this case are not a continuous function of institutional reform so we cannot rely on a firstorder condition. For comparative purposes, however, it is instructive to analyze a

\footnotetext{
${ }^{4}$ These outcomes correspond to three distinct points along the so-called J-curve of reform, a continuous representation of welfare as a function of reform progress. The status quo, from this perspective, represents an intermediate level of welfare, which is expected to deteriorate in the "valley of transition" before improving (see, for example, Przeworski, 1991).
} 
benchmark case in which the probability of reelection is exogenous - that is, not a function of $\sigma$. In this case it is easy to see that the committed reformer's optimal institutional reform is given by $\tilde{\sigma}$, while

$$
\sigma_{o}^{*}=\tilde{\sigma}-\operatorname{Pr}(\cdot) \lambda B
$$

defines optimal political constraint for the opportunist (denoted by the subscript $o$ ). The relationship $\sigma_{o}^{*}<\tilde{\sigma}$ clearly holds as long as $\operatorname{Pr}(\cdot)>0$. Hence, an opportunist would undoubtedly choose a lower level of constraints than a committed reformer if no strategic electoral concerns were involved.

By contrast, where the probability of reelection is a function of $\sigma$, the chance of the incumbent's reelection increases as the percentage of voters who believe that the incumbent is a genuine reformer increases. Hence, opportunists will face incentives to mimic committed reformers, whereas committed reformers will try to distinguish themselves from the opportunists. Both incentives work in the direction of greater constraints than that given in equation (8). Depending on the parameters of the model, it is possible to identify two different outcomes: first, a separating equilibrium in which the two types choose different $\sigma$ and in which voters, being able to anticipate this, can tell the types apart; and second, a pooling equilibrium in which the opportunists mimic the reformers who, in turn, find it too costly to distinguish themselves from the opportunists, thus forcing voters to base their decision on prior expectations.

It is possible to specify the conditions under which a separating equilibrium exists as follows. There must exist a $\sigma^{* *}>\tilde{\sigma}$ such that (1) the committed reformer is better off choosing $\sigma^{* *}$ in order to be distinguished from the opportunist than choosing $\tilde{\sigma}$ and having the opportunist masquerade as a committed reformer, and (2) the opportunist is better off choosing $\sigma_{o}^{*}$ than mimicking the committed reformer and choosing $\sigma^{* *}$ even though this means that the opportunist's type is revealed. If the set of such $\sigma^{* *}$ contains more than one element, then the committed reformer will select the lowest level of institutional reforms within that set. Formally, we can define these conditions as

$$
\begin{aligned}
& -\frac{\left(\sigma^{* *}-\tilde{\sigma}\right)^{2}}{2}+G[\delta(x) u(R)+(1-\delta(x)) u(Q)-u(Q)] V> \\
& G[\alpha(\delta(x) u(R)+(1-\delta(x)) u(Q))+(1-\alpha) u(E, x)-u(Q)] V
\end{aligned}
$$

and

$$
\begin{aligned}
&-\frac{\left(\sigma_{o}^{*}-\tilde{\sigma}\right)^{2}}{2}+G[u(E, x)-u(Q)]\left(1-\sigma_{o}^{*}\right) \lambda B> \\
&-\frac{\left(\sigma^{* *}-\tilde{\sigma}\right)^{2}}{2}+ G[\alpha(\delta(x) u(R)+(1-\delta(x)) u(Q)) \\
&+(1-\alpha) u(E, x)-u(Q)]\left(1-\sigma^{* *}\right) \lambda B .
\end{aligned}
$$


Figure 3. Pooling versus Separating Equilibria

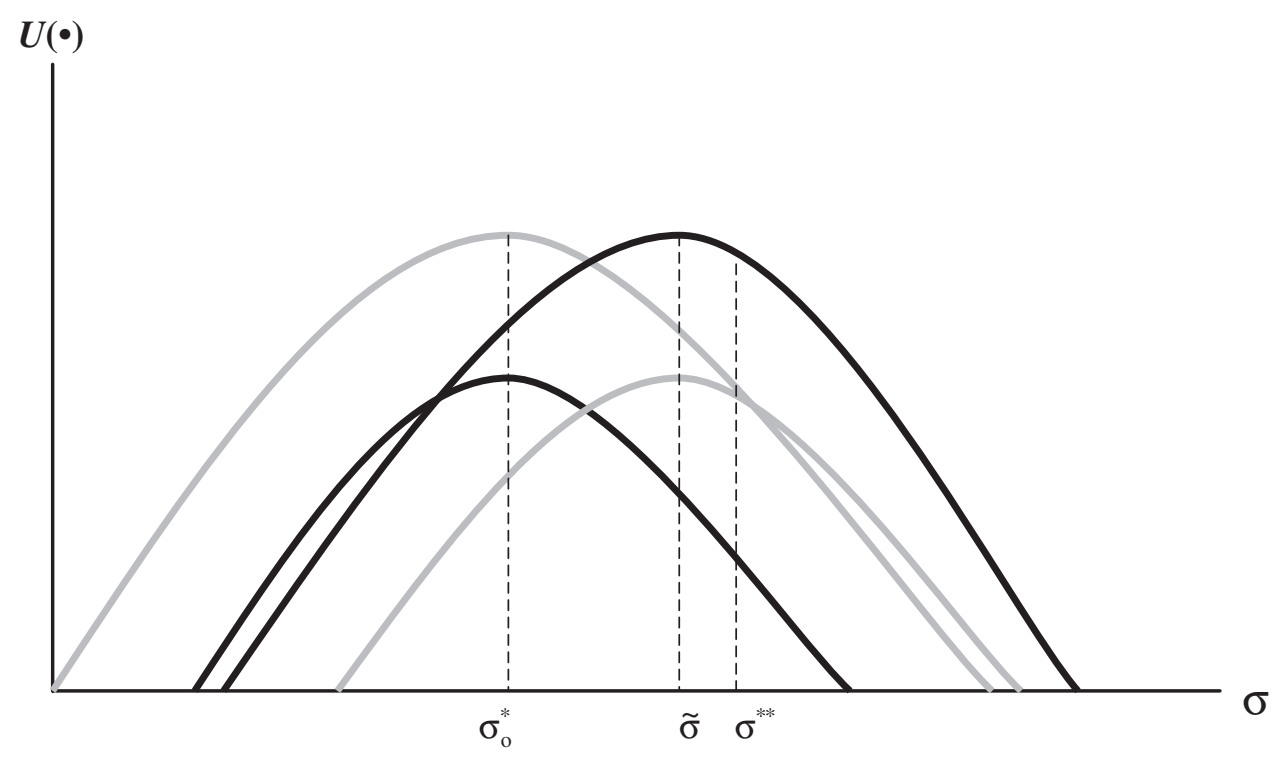

Notes: $\sigma$ is the level of political constraint.

Figure 3 shows utility as a function of $\sigma$, with the two leftmost functions corresponding to the opportunist, and the two rightmost functions corresponding to the committed reformer. The shaded lines represent respective types' utility in the pooling equilibrium, and the black lines correspond to the utility in the separating equilibrium. Note that the opportunist is better off in the pooling equilibrium for any choice of $\sigma$, whereas the reformer is better off in the separating equilibrium. Consider the case in which both types choose their unconstrained best- $\sigma_{o}^{*}$ and $\tilde{\sigma}$, respectively. This would correspond to a separating equilibrium because voters can identify incumbent type through the choice of $\sigma$, so utility is represented by the solid lines. There are clearly no incentives for reformers to deviate from this strategy unilaterally; opportunists, however, can increase their utility by mimicking reformers and choosing $\tilde{\sigma}$. Hence, this cannot be an equilibrium.

This does not mean, however, that there exists a pooling equilibrium. This can exist only if the committed reformer is better off choosing $\tilde{\sigma}$ (when the reformer is being mimicked by the opportunist) than choosing some $\sigma^{* *}>\tilde{\sigma}$ such that the opportunist is better off not mimicking. As Figure 3 is drawn, the condition for a pooling equilibrium is violated. That is, there exists a $\sigma^{* *}$ such that the utility of the committed reformer (in this instance, represented by the solid line) is higher than when choosing $\tilde{\sigma}$ (represented by the shaded line), whereas the opportunist is better off choosing $\sigma_{o}^{*}$ than choosing $\sigma^{* *}$ and pretending to be a reformer.

The model shows how private information creates incentives for both types of reformers to extend political-institutional reforms to boost their political support. Opportunists will implement institutional reforms to mask their true intentions from voters in the pooling equilibrium, whereas the genuine reformers will over- 
shoot in order to separate themselves from the opportunists in the separating equilibrium. Private information creates a link from political constraints to public support for markets because constraints effectively signal a lower risk of expropriation. We can summarize this first outcome by the following hypothesis:

Hypothesis 1: Support for market reforms is an increasing function of political constraints.

The reform experiences of lower- and middle-income countries, of course, typically involve a protracted sequence of many different, discrete policies. In latter stages, there is typically an increase in the number and variety of actors who must collaborate, as well as the amount of information necessary, to design and implement major policy changes. Successive reform phases, therefore, will become harder to implement. As we argued above, the consequences of expropriation are likely to be greater in the initial phases of the reform process. To see clearly the effect of reform maturity on the incentives to separate and mimic, we assume that $G(\cdot)$ is uniform with support on $[0,1] .^{5}$ This implies that $G(\varepsilon)=\varepsilon$, and with some reshuffling the two conditions for a separating equilibrium can be rewritten as

$$
(1-\alpha)[\delta(x)(u(R)-u(Q))+(u(Q)-u(E, x))] V>\frac{\left(\sigma^{* *}-\tilde{\sigma}\right)^{2}}{2}
$$

and

$$
\begin{aligned}
& \lambda \beta[\alpha \delta(x)(u(R)-u(Q))+(u(Q)-u(E, x))\left(\alpha\left(1-\sigma^{* *}\right)\right. \\
&\left.+\left(\sigma^{* *}-\sigma_{o}^{*}\right)\right]<\frac{\left(\sigma^{* *}-\tilde{\sigma}\right)^{2}}{2}-\frac{\left(\sigma^{*}-\tilde{\sigma}\right)^{2}}{2} .
\end{aligned}
$$

The left-hand sides of the two inequalities show the political benefits to the committed reformer of separating from the opportunist, and to the opportunist of mimicking the committed reformer, respectively. Both of these benefits weaken as reform maturity $(x)$ increases. The committed reformer will face reduced incentives to impose far-reaching institutional reforms that signal type because voters know that both the cost of expropriation and the probability of successful economic reform are smaller. On the other hand, this also implies that the political cost to the opportunists of being unmasked is lower, and they will thus have fewer incentives to mimic reformers. Hence, the effect on the likelihood of a separating rather than a pooling equilibrium is uncertain, but the political gain from further institutional reforms is unambiguously lower. This implies the following relationship among political constraints, popular support, and reform maturity:

Hypothesis 2: The effect of political constraints on popular support for market reforms is weakening as the reform process matures.

${ }^{5}$ This assumption merely simplifies the exposition; it is by no means necessary for the result. 


\section{Data, Estimation, and Results}

\section{Variables and Data Sources}

Our central dependent variable-support for reform-is taken from two sets of regional opinion surveys: the Central and Eastern European Barometer (CEEB) and the Latinobarómetro (LB). The CEEB was conducted in 16 transition economies between 1990 and 1997, and the LB has surveyed 17 countries each year since 1996. ${ }^{6}$ Following previous analyses of reform support in Eastern Europe/CIS (Kim and Pirttilä, 2003) and Latin America (Lora, Panizza, and Quispe-Agnoli, 2004), we define support for reform as the share (by country) of respondents who answer in the affirmative, less the share of respondents who answer in the negative, to a survey question on whether respondents believe that a market economy is in the country's best interest. ${ }^{7}$

Following the model, we hypothesize that institutional constraints on executive power will influence support for market-based reforms and that this effect will be conditioned on progress in previous reform efforts. As a measure of institutional constraints, we use a widely available measure of the effective number of veto players in the political system (Henisz, 2000). This "political constraints" index relies upon a simple spatial model to assess the extent to which politicians are constrained in decision making, adjusted for diminishing returns to additional veto players.

To approximate the degree of progress in reforms, we derive an indicator of structural reform based on the extent of price and trade liberalization, currency con-

\footnotetext{
${ }^{6}$ Our core sample includes the following countries from each region: Argentina, Bolivia, Brazil, Chile, Colombia, Costa Rica, Dominican Republic, Ecuador, Mexico, Panama, Paraguay, Peru, Uruguay, and Venezuela (in Latin America); Armenia, Belarus, Bulgaria, Czech Republic, Estonia, Hungary, Latvia, Lithuania, Poland, Romania, Russia, Slovak Republic, Slovenia, and Ukraine (in Eastern Europe/CIS). The question regarding support for a market economy - the responses to which we use to construct our indicator of support for market reform - has only appeared in LB surveys since 1998. Consequently, time periods also differ across regional groups (1990 to 1997 for Eastern Europe/CIS, and 1998 to 2002 for Latin America). When pooling the samples, we compensate for these different period observations, as noted below, by including time dummies in our benchmark specifications. Note, finally, that surveys conducted in the former Czechoslovakia and U.S.S.R. were republic-specific, allowing us to compare responses before and after the breakups of these unions.

${ }^{7}$ These questions are worded slightly differently between surveys. In the CEEB:

Do you personally feel that the creation of a free-market economy, that is, one free from state control, is right or wrong for our country's future?

In the LB:

Do you somewhat agree, somewhat disagree, or strongly disagree [with the following phrase]: a market economy is best for the country?

Note that this different wording creates some problems for comparison between the two regions. First, in the CEEB survey, the "future" is explicitly stated in the question, whereas in the LB survey it is not. Second, possible answers to the CEEB question are "right," "wrong," or "don't know," but in the LB survey there are three possible answers in addition to "don't know." Although there are no perfect corrections for these differences, we feel that the benefits from cross-regional comparison far outweigh the potential for misinterpretation. We try to make responses to these questions comparable by performing two corrections. First, rather than estimating solely the percentages that responded "agree" or "right," we subtract the percentage that answered in the negative from the percentage that answered in the affirmative to determine the "net support" for market-based reforms. Second, when pooling responses, we always use country fixed effects as a robustness check to correct for any country- or region-specific effects that cannot be readily observed, including differences in the implementation of the surveys.
} 
vertibility, and privatization. For Eastern Europe/CIS and Latin America, the indicators are taken from two separate World Bank structural reform indices (De Melo, Denizer, and Gelb, 1996; and World Bank, 2004b, respectively), both of which incorporate internal and external reforms, including reforms to prices, trade, and financial and public sectors. There is no structural reform index that is strictly comparable between these two regions, given the disparity in reform imperatives, sequences, and programs. In addition to estimating relationships by regional subsample, therefore, we also normalize both indices by regional maxima and minima to yield an index ranging from 0 (least reformed) to 1 (most reformed) when pooling our samples. Finally, we also include the following variables to control for purely economic voting: inflation (in natural logs), GDP per capita, the unemployment rate, GDP per capita growth, and the Gini coefficient. A time trend is also included in all specifications. Descriptive statistics for all variables by subsample are listed in Table 1.

\section{Results}

Our initial results are presented in Table 2. Estimation is by ordinary least squares (OLS), with standard errors adjusted for correlation across panels (Beck, 2001).

Table 1. Descriptive Statistics by Regional Subsamples

\begin{tabular}{|c|c|c|c|c|c|c|}
\hline & \multicolumn{4}{|c|}{ Standard Deviation } & \multirow[b]{2}{*}{ Minimum } & \multirow[b]{2}{*}{ Maximum } \\
\hline & Mean & Between & Within & Overall & & \\
\hline \multicolumn{7}{|l|}{ Eastern Europe/CIS ${ }^{1}$} \\
\hline Support for reform & 10.86 & 21.27 & 14.70 & 23.94 & -46.26 & 63.86 \\
\hline Inflation & 5.28 & 0.78 & 0.65 & 0.91 & 4.66 & 9.24 \\
\hline GDP per capita & 7.88 & 0.63 & 0.11 & 0.58 & 6.64 & 9.23 \\
\hline Unemployment & 8.25 & 4.29 & 2.23 & 4.59 & 0.08 & 16.40 \\
\hline Growth & -2.03 & 5.28 & 6.82 & 8.19 & -34.86 & 10.62 \\
\hline Gini & 31.10 & 6.38 & 3.32 & 6.94 & 18.85 & 48.30 \\
\hline Political constraint & 0.37 & 0.17 & 0.14 & 0.22 & 0.00 & 0.65 \\
\hline Polity index & 0.87 & 0.17 & 0.80 & 0.16 & 0.15 & 1.00 \\
\hline Reform & 0.74 & 0.20 & 0.13 & 0.22 & 0.07 & 1.00 \\
\hline \multicolumn{7}{|l|}{ Latin America ${ }^{2}$} \\
\hline Support for reform & 33.25 & 14.48 & 7.43 & 15.73 & 4.13 & 62.20 \\
\hline Inflation & 4.71 & 0.11 & 0.05 & 0.13 & 4.59 & 5.28 \\
\hline GDP per capita & 8.10 & 0.59 & 0.03 & 0.56 & 6.84 & 9.07 \\
\hline Unemployment & 10.14 & 4.32 & 1.40 & 4.48 & 2.10 & 20.50 \\
\hline Growth & -0.15 & 1.81 & 2.77 & 3.29 & -7.93 & 6.89 \\
\hline Gini & 51.62 & 5.07 & 0.75 & 4.89 & 42.70 & 58.60 \\
\hline Political constraint & 0.42 & 0.19 & 0.08 & 0.17 & 0.00 & 0.65 \\
\hline Polity index & 0.89 & 0.08 & 0.06 & 0.10 & 0.55 & 1.00 \\
\hline Reform & 0.59 & 0.10 & 0.04 & 0.10 & 0.38 & 0.81 \\
\hline
\end{tabular}




\begin{tabular}{|c|c|c|c|c|}
\hline & $\begin{array}{l}\text { Full Sample } \\
\text { (1) }\end{array}$ & $\begin{array}{l}\text { Latin America } \\
\text { (2) }\end{array}$ & $\begin{array}{c}\text { Eastern } \\
\text { Europe/CIS } \\
\text { (3) }\end{array}$ & $\begin{array}{l}\text { Full Sample } \\
\text { (4) }\end{array}$ \\
\hline Inflation & $\begin{array}{c}-6.8975 \\
(4.6953)\end{array}$ & $\begin{array}{c}3.1822 \\
(7.9625)\end{array}$ & $\begin{array}{c}-0.4662 \\
(2.4862)\end{array}$ & $\begin{array}{c}-1.3670 \\
(2.5598)\end{array}$ \\
\hline GDP per capita & $\begin{array}{l}-2.6865 \\
(3.8242)\end{array}$ & $\begin{array}{l}-8.8011 * * * \\
(1.2546)\end{array}$ & $\begin{array}{l}-4.2920 \\
(5.0447)\end{array}$ & $\begin{array}{l}-8.2978 * * * \\
(2.2691)\end{array}$ \\
\hline Unemployment & $\begin{array}{c}0.4067 \\
(0.3554)\end{array}$ & $\begin{array}{c}-0.2817 \\
(0.3488)\end{array}$ & $\begin{array}{c}0.7932 \\
(0.5807)\end{array}$ & $\begin{array}{c}0.4645 \\
(0.3658)\end{array}$ \\
\hline Growth & $\begin{array}{c}-0.0015 \\
(0.2969)\end{array}$ & $\begin{array}{l}-0.3639 \\
(0.2645)\end{array}$ & $\begin{array}{c}0.1840 \\
(0.2919)\end{array}$ & $\begin{array}{c}0.1838 \\
(0.2176)\end{array}$ \\
\hline Gini & $\begin{array}{l}0.8572 * * \\
(0.3865)\end{array}$ & $\begin{array}{c}0.2378 \\
(0.2724)\end{array}$ & $\begin{array}{l}-1.0075 * * \\
(0.4259)\end{array}$ & $\begin{array}{c}-0.7506 * * \\
(0.3456)\end{array}$ \\
\hline Political constraint & $\begin{array}{c}19.5370 \\
(13.9901)\end{array}$ & $\begin{array}{l}-22.1266 * * * \\
(5.2789)\end{array}$ & $\begin{array}{l}38.0520 * * * \\
(14.5754)\end{array}$ & $\begin{array}{l}44.9261 * * * \\
(14.4419)\end{array}$ \\
\hline \multicolumn{2}{|l|}{ Latin America } & & & $\begin{array}{l}95.4832 * * * \\
(11.6534)\end{array}$ \\
\hline \multicolumn{2}{|l|}{$\begin{array}{l}\text { Political constraint } \times \\
\text { Latin America }\end{array}$} & & & $\begin{array}{l}-71.6009 * * * \\
(15.3922)\end{array}$ \\
\hline Trend & $\begin{array}{l}-1.8913 \\
(1.6731)\end{array}$ & $\begin{array}{l}-5.5435 * * * \\
(1.4316)\end{array}$ & $\begin{array}{l}-4.6103 * * \\
(1.8089)\end{array}$ & $\begin{array}{l}-5.2115 * * * \\
(1.2433)\end{array}$ \\
\hline Number of observations & 139 & 59 & 80 & 139 \\
\hline Number of countries & 30 & 16 & 14 & 30 \\
\hline$R^{2}$ & 0.2633 & 0.7415 & 0.3259 & 0.5316 \\
\hline$\rho$ & 0.5618 & 0.6428 & 0.5302 & 0.5527 \\
\hline $\begin{array}{l}\text { Wald } \chi^{2} \\
\left(\text { Prob. }>\chi^{2}\right)\end{array}$ & $\begin{array}{l}11.27 \\
(0.1272)\end{array}$ & $\begin{array}{l}257.11 \\
(0.0000)\end{array}$ & $\begin{array}{l}40.79 \\
(0.0000)\end{array}$ & $\begin{array}{l}218.85 \\
(0.0000)\end{array}$ \\
\hline $\begin{array}{l}\text { Source: Authors' ca } \\
\text { Notes: Dependent v } \\
\text { corrections for contem } \\
\text { Coefficients on intercept }\end{array}$ & $\begin{array}{l}\text { ons. } \\
\text { is support for } \\
\text { ous and seria } \\
\text { not reported. S }\end{array}$ & $\begin{array}{l}\text { form. Estimation } \\
\text { orrelation. Panel } \\
\text { ificance: } * * p<\end{array}$ & $\begin{array}{l}\text { with ordinary } \\
\text { rrect errors a } \\
5, * * * p<0.0\end{array}$ & $\begin{array}{l}\text { st squares with } \\
\text { in parentheses. }\end{array}$ \\
\hline
\end{tabular}

We also model the error term as a first-order autocorrelated process, that is, $v_{i t}=\mu_{i t}+\rho v_{i t-1}$, and report rho $(\rho)$ values. The resulting estimation thus yields "panel-correct" standard errors, corrected for both contemporaneous and serial correlation. Column (1) shows results when country-year observations for both regions are pooled; in this specification, only the level of inequality has any effect on support for reform, whereas the measure of political constraints has no significant effect. In the next two estimations, we separate the sample between Latin American and Eastern European subsamples (16 and 14 countries, respectively). Separating the sample in this way shows diverging effects of executive constraints between regions. In Latin America, an increase of one standard deviation in the level of political constraints lowers public support for markets by 5 percentage points; in Eastern Europe, a similar increase boosts support for markets by 12 percentage points. ${ }^{8}$ This

\footnotetext{
${ }^{8}$ These and the subsequent estimated values are obtained holding all other variables at their means.
} 
divergence is shown again when we re-pool the samples, add a regional dummy, and interact this regional dummy with the political constraints index.

Table 3 presents the main tests of our central hypotheses. We include the regionnormalized measure of cumulative structural reform, lagged once, and interact this term with the political constraints index in column (1). In this specification, a onestandard-deviation increase in the political constraints index alone increases support for markets by more than 22 percentage points. A combined increase in both the constraints index and the lagged reform index by a single standard deviation, however, increases support by a mere 2 percentage points. Note that the degree of cumulative progress in reform itself does not have any statistically significant impact on support for markets, suggesting that market reforms alone do not generate or dissipate future

\begin{tabular}{|c|c|c|c|c|}
\hline & $\begin{array}{c}\text { Panel-Correct }{ }^{1} \\
\text { (1) }\end{array}$ & $\begin{array}{c}\text { Two-Way } \\
\text { Fixed Effects }{ }^{2} \\
\text { (2) }\end{array}$ & $\begin{array}{l}\text { Panel-Correct }{ }^{1} \\
\text { Latin America } \\
\text { (3) }\end{array}$ & $\begin{array}{l}\text { Panel-Correct }{ }^{1} \\
\text { E. Europe } \\
\text { (4) }\end{array}$ \\
\hline Inflation & $\begin{array}{l}-6.3656 \\
(4.1242)\end{array}$ & $\begin{array}{l}-1.8669 \\
(3.3544)\end{array}$ & $\begin{array}{l}21.2256 * * \\
(9.5635)\end{array}$ & $\begin{array}{l}-0.0993 \\
(2.5835)\end{array}$ \\
\hline GDP per capita & $\begin{array}{c}4.9030 \\
(4.8809)\end{array}$ & $\begin{array}{l}55.9981 * * * \\
(19.9990)\end{array}$ & $\begin{array}{l}-8.7816 * * * \\
(3.0125)\end{array}$ & $\begin{array}{l}-0.3069 \\
(4.6275)\end{array}$ \\
\hline Unemployment & $\begin{array}{c}0.3151 \\
(0.4143)\end{array}$ & $\begin{array}{l}-0.6775 \\
(0.8106)\end{array}$ & $\begin{array}{l}-0.1217 \\
(0.3583)\end{array}$ & $\begin{array}{c}0.2641 \\
(0.6800)\end{array}$ \\
\hline Growth & $\begin{array}{c}0.2569 \\
(0.2796)\end{array}$ & $\begin{array}{c}-0.4542 \\
(0.3156)\end{array}$ & $\begin{array}{l}-0.3237 \\
(0.3449)\end{array}$ & $\begin{array}{c}0.4236 \\
(0.3224)\end{array}$ \\
\hline Gini & $\begin{array}{c}0.4043 \\
(0.3502)\end{array}$ & $\begin{array}{l}-2.4813 * * * \\
(0.6236)\end{array}$ & $\begin{array}{c}-0.1997 \\
(0.1582)\end{array}$ & $\begin{array}{l}-1.0604 * * * \\
(0.3796)\end{array}$ \\
\hline Political constraint & $\begin{array}{l}88.3994 * * * \\
(26.9313)\end{array}$ & $\begin{array}{l}120.5693 * * * \\
(25.9895)\end{array}$ & $\begin{array}{l}198.7487 * * \\
(78.5586)\end{array}$ & $\begin{array}{l}105.9750 * * * \\
(26.9750)\end{array}$ \\
\hline $\operatorname{Reform}_{(-1)}$ & $\begin{array}{c}2.1272 \\
(23.1488)\end{array}$ & $\begin{array}{l}47.5353 * * \\
(22.6146)\end{array}$ & $\begin{array}{l}154.3879 * * * \\
(55.0458)\end{array}$ & $\begin{array}{c}18.8392 \\
(19.6613)\end{array}$ \\
\hline $\begin{array}{l}\text { Political constraints } \times \\
\text { Reform }_{(-1)}\end{array}$ & $\begin{array}{c}-106.1204 * * \\
(45.4419)\end{array}$ & $\begin{array}{l}-126.6035^{* * *} \\
(39.5901)\end{array}$ & $\begin{array}{l}-376.0866 * * * \\
(126.3432)\end{array}$ & $\begin{array}{c}-110.3526 * * * \\
(42.1498)\end{array}$ \\
\hline Trend & $\begin{array}{c}-1.6318 \\
(1.3015)\end{array}$ & $\begin{array}{c}-1.5826 \\
(1.7291)\end{array}$ & $\begin{array}{l}-5.3583 * * * \\
(1.0785)\end{array}$ & $\begin{array}{c}-4.0631 * * \\
(1.7128)\end{array}$ \\
\hline Number of observations & 127 & 127 & 48 & 79 \\
\hline Number of countries & 27 & 27 & 13 & 14 \\
\hline$R^{2}$ & 0.3067 & 0.5201 & 0.6192 & 0.4003 \\
\hline$\rho$ & 0.5407 & & 0.3056 & 0.4987 \\
\hline $\begin{array}{l}\text { Wald } \chi^{2} / F \text { Test } \\
\left.\text { (Prob. }>\chi^{2} / F\right)\end{array}$ & $\begin{array}{l}34.86 \\
(0.0001)\end{array}$ & $\begin{array}{l}5.29 \\
(0.0000)\end{array}$ & $\begin{array}{c}1343.89 \\
\quad(0.0000)\end{array}$ & $\begin{array}{l}61.95 \\
(0.0000)\end{array}$ \\
\hline \multicolumn{5}{|c|}{$\begin{array}{l}\text { Notes: Dependent variable is support for reform. Coefficients on intercepts are not reported. } \\
\text { Significance: } * * p<0.05, * * * p<0.01 \text {. } \\
{ }^{1} \text { Estimation is performed using ordinary least squares with corrections for contemporaneous and } \\
\text { serial correlation. Panel-correct errors are in parentheses. } \\
{ }^{2} \text { Estimation is performed using country fixed effects and time dummies. Standard errors are in } \\
\text { parentheses. }\end{array}$} \\
\hline
\end{tabular}


support for markets in any appreciable way. Rather, progress in reform conditions the effect of institutional constraints on the legitimacy of markets.

Recall that the pooled sample combines two regions and time periods in which different reform requisites were evident. To be sure, the character of reforms in transition economies in the early to mid-1990s is quite different from that of reforms in Latin America in the last half of the 1990s. Thus in column (2) we rerun the previous estimation using two-way fixed effects to correct for these potential year- and country-specific factors. In this specification, our previous results are replicated, suggesting that the relationship among reform progress, political constraint, and support for markets holds across time and country. Finally, as a further demonstration of the universality of these relationships, in columns (3) and (4) we rerun our basic interactive specification within regional subsamples. Although there are some differences in the statistical significance of some variables - particularly the Gini coefficient and the lagged reform index — our basic results remain constant across regions. Political constraints boost support for markets, but this effect is decreasing as cumulative reforms proceed. This effect can be seen graphically in Figure 4, which plots the conditional effect of political constraints on support across levels of cumulative reform (the solid line), with 95 percent confidence intervals (the shaded lines).

Political constraints - essentially, institutionalized commitments to limit executive power and to protect individual and collective liberties from state authority-

\section{Figure 4. Conditional Effects with \pm 95 Percent Confidence Intervals}

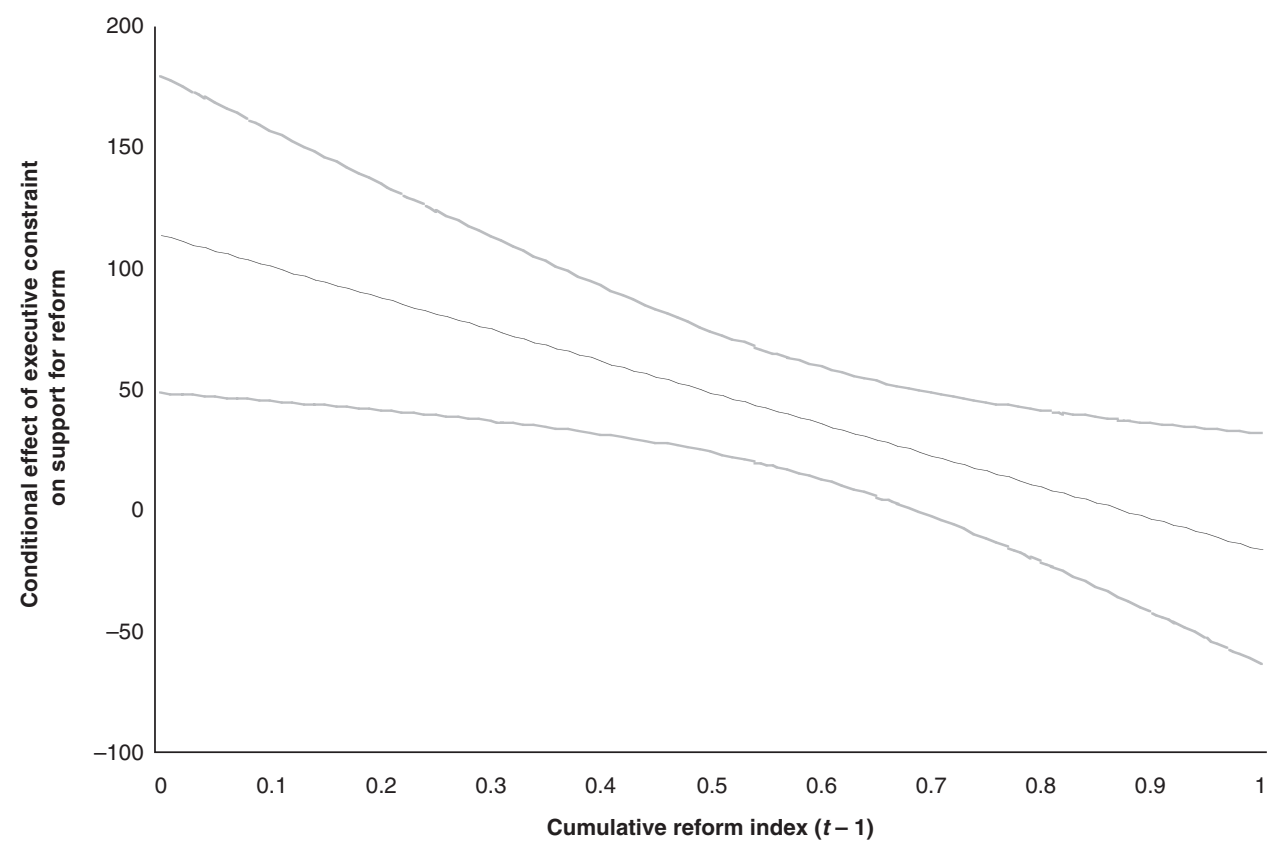

Source: Authors' calculations.

Notes: The figure plots the predicted effect of executive constraints on support for reform given the level of cumulative reform, based on regression model (4) in Table 4. 
are only one mechanism that can enhance accountability in government. The other is democratic procedure - namely, citizen representation through contested elections; one of the central tenets of democratic theory is that elections constitute a sanctioning device that induces public officials to do what voters want (Ferejohn, 1986; and Manin, 1997). In one sense, political constraints and elections are complementary: elections have been considered a "vertical" mechanism for accountability, whereas separations of power and the presence of veto players are a "horizontal" mechanism in that they require accountability between different branches of government (O’Donnell, 1994). Consequently, it remains to be determined whether elections in which citizens are able to select reform-oriented politicians can serve a parallel function as a political constraint in raising popular support for markets.

Table 4 presents our empirical observations of the effects of democratic elections. Column (1) replicates the first regression from Table 3, with the exception that we substitute a measure of democratic contestation for political constraint. We use the familiar Polity index of democracy, which is based on measures of the openness of political participation and the level of competition in the selection of political leaders (Marshall and Jaggers, 2001). ${ }^{9}$ The Polity index has a similar effect on support for markets as political constraint in both panel-correct and two-way fixed-effects regressions. Once we include both measures in the same regressions (columns (3) and (4)), however, the effect of the Polity index disappears.

This suggests that democratic elections are a relatively weaker accountability mechanism than institutional constraints. Indeed there is evidence that several regimes in Latin America and Eastern Europe/CIS hold relatively free elections but have failed to restrict governmental authority or to protect basic rights (Plattner, 1999). Other analysts, similarly, have argued that elections are less likely to serve as sanctioning devices but rather are more likely to be perceived by voters as opportunities to chose "good" over "bad" politicians, with little expectation of accountability (Fearon, 1999). There is also the possibility that, simply stated, political representation may not achieve accountability as well as expected in reforming governments and that citizen control over politicians in these countries is imperfect.

\section{Conclusions and Implications}

At the heart of the issues addressed here lies a question that reformist governments have often faced at the outset of their tenure: to what extent should reforms, in addition to implementing market-oriented prescriptions, extend to remaking the institutions of the state? Debates on the pace and sequence of the transition in formerly socialist economies addressed the relative advantages of executive constraints versus executive discretion, with "shock therapy" advocates concerned that changes in political rules would divert resources from more important market-reform components and with others arguing that a new constitutional order characterized by constraints on state power would reduce the risks of rent seeking. Analyses of the so-called second stage of reforms in Latin America have similarly been cloaked in

${ }^{9}$ The polity ranges from -10 to +10 . We rescale as $(10+$ polity $) / 20$ to yield a score that ranges from 0 (least democratic) to 1 (most democratic). 
Table 4. Political Constraint, Political Democracy, and Support for Reform

\begin{tabular}{|c|c|c|c|}
\hline & Two-Way & & Two-Way \\
\hline Panel-Correct ${ }^{1}$ & Fixed Effects ${ }^{2}$ & Panel-Correct ${ }^{1}$ & Fixed Effects \\
\hline
\end{tabular}

\begin{tabular}{|c|c|c|c|c|}
\hline Inflation & $\begin{array}{c}-11.7856 * * * \\
(2.5429)\end{array}$ & $\begin{array}{l}-3.5552 \\
(2.9551)\end{array}$ & $\begin{array}{l}-7.5206 * * * \\
(2.5411)\end{array}$ & $\begin{array}{c}0.4273 \\
(3.6714)\end{array}$ \\
\hline GDP per capita & $\begin{array}{c}1.9815 \\
(5.4585)\end{array}$ & $\begin{array}{c}22.1116 \\
(18.0859)\end{array}$ & $\begin{array}{c}1.3184 \\
(4.1406)\end{array}$ & $\begin{array}{l}54.4787 * * \\
(22.6645)\end{array}$ \\
\hline Unemployment & $\begin{array}{c}0.3680 \\
(0.5363)\end{array}$ & $\begin{array}{r}-0.6619 \\
(0.8887)\end{array}$ & $\begin{array}{c}0.1290 \\
(0.4915)\end{array}$ & $\begin{array}{c}-0.5244 \\
(0.8436)\end{array}$ \\
\hline Growth & $\begin{array}{c}0.2108 \\
(0.2211)\end{array}$ & $\begin{array}{c}-0.0979 \\
(0.3280)\end{array}$ & $\begin{array}{l}0.4632 * \\
(0.2730)\end{array}$ & $\begin{array}{l}-0.4733 \\
(0.3290)\end{array}$ \\
\hline Gini & $\begin{array}{c}0.5328 \\
(0.3810)\end{array}$ & $\begin{array}{l}-1.9133 * * * \\
(0.6594)\end{array}$ & $\begin{array}{c}0.3213 \\
(0.3844)\end{array}$ & $\begin{array}{l}-2.4984 * * * \\
(0.6670)\end{array}$ \\
\hline Polity index & $\begin{array}{l}110.2778^{*} \\
(65.4844)\end{array}$ & $\begin{array}{l}122.5492 * * \\
(54.4044)\end{array}$ & $\begin{array}{c}80.1338 \\
(60.4276)\end{array}$ & $\begin{array}{l}28.4906 \\
(64.3184)\end{array}$ \\
\hline $\operatorname{Reform}_{(-1)}$ & $\begin{array}{c}44.6561 \\
(99.9690)\end{array}$ & $\begin{array}{l}194.1664 * * \\
(83.7050)\end{array}$ & $\begin{array}{c}29.6837 \\
(88.2919)\end{array}$ & $\begin{array}{c}86.9674 \\
(91.4376)\end{array}$ \\
\hline Polity index $\times$ reform $_{(-1)}$ & $\begin{array}{c}-92.6400 \\
(111.8581)\end{array}$ & $\begin{array}{l}-220.1511 * * \\
(98.0383)\end{array}$ & $\begin{array}{l}-31.3971 \\
(99.5162)\end{array}$ & $\begin{array}{c}-27.9077 \\
(118.5737)\end{array}$ \\
\hline Political constraint & & & $\begin{array}{l}90.7345 * * * \\
(29.6511)\end{array}$ & $\begin{array}{l}123.4656^{* * * *} \\
(37.4415)\end{array}$ \\
\hline $\begin{array}{l}\text { Political constraint } \times \\
\quad \text { reform }_{(-1)}\end{array}$ & & & $\begin{array}{l}-133.1945 * * * \\
(44.6775)\end{array}$ & $\begin{array}{c}-138.8245^{* * *} \\
(57.3553)\end{array}$ \\
\hline Trend & $\begin{array}{l}-1.8664 \\
(1.4512)\end{array}$ & $\begin{array}{c}0.4236 \\
(1.9715)\end{array}$ & $\begin{array}{c}-1.7457 \\
(1.3327)\end{array}$ & $\begin{array}{c}-1.4705 \\
(1.9066)\end{array}$ \\
\hline Number of observations & 126 & 126 & 123 & 123 \\
\hline Number of countries & 27 & 27 & 27 & 27 \\
\hline $\begin{array}{l}R^{2} \\
\rho\end{array}$ & $\begin{array}{l}0.3384 \\
0.6876\end{array}$ & 0.3427 & $\begin{array}{l}0.3781 \\
0.6351\end{array}$ & 0.4637 \\
\hline $\begin{array}{l}\text { Wald } \chi^{2} / F \text { Test } \\
\text { (Prob. }>\chi^{2} / F \text { ) }\end{array}$ & $\begin{array}{l}48.81 \\
(0.0000)\end{array}$ & $\begin{array}{l}2.52 \\
(0.0030)\end{array}$ & $\begin{array}{l}517.41 \\
(0.0000)\end{array}$ & $\begin{array}{l}3.50 \\
(0.0000)\end{array}$ \\
\hline
\end{tabular}

Source: Authors' calculations.

Notes: Dependent variable is support for reform. Coefficients on intercepts are not reported. Significance: $* p<0.10, * * p<0.05, * * * p<0.01$.

${ }^{1}$ Estimation is performed using ordinary least squares with corrections for contemporaneous and serial correlation. Panel-correct errors are in parentheses.

${ }^{2}$ Estimation is performed using country fixed effects and time dummies. Standard errors are in parentheses.

the language of "good government," in which the professionalization of the civil service as well as the autonomization of legislatures, of subnational governments, and of the judiciary have emerged as important goals.

This paper analyzed the effects of political constraints on public opinion toward markets. We proposed a simple model in which politicians could signal their willingness to prevent expropriation by elites and thus convince voters that the benefits of reform would be widely shared. Data taken from public opinion barometers in Eastern Europe and in Latin America in the 1990s showed that the creation of 
checks and balances and other mechanisms that limit executive-branch power increases the popularity of markets. The magnitude of this effect is heightened in the earlier phases of reform, when the risk of expropriation by elites is perceived to be the greatest, and diminishes as reforms proceed. With reform maturity, the risk of expropriation is gradually supplanted by the risk of fragmentation and stalemate and of intransigent conflicts between supporters and opponents of specific reform programs. Strengthened political constraints do little to lessen these risks.

Greater appreciation of the vital functions that legitimacy and trust in markets play in undergirding and sustaining economic reforms is needed. And a better understanding of what sways public opinion should be a prominent part of any assessment of reform feasibility. If the analysis presented above is correct, however, it offers several implications for reform strategies as they are commonly carried out. We mention two such implications here.

First, a reliance on communicating the benefits of economic reforms through general public relations efforts or through informational campaigns focused on specific segments of the population may easily fail to change minds in the earlier stages of reform. It is always difficult for reformers or their agents to communicate credibly to voters, and it is most difficult in the early phases when the costs and benefits of reform are unclear. But although talk is cheap, institutional reforms that limit state power are not. They are also the clearest signals that a narrow class of elites will not enrich themselves at the expense of the public.

Second, external "anchors"-in the form of international financing and trading agreements, treaties, regional unions, and so on-may also fail to raise support for market reform. A perceived commitment from reformers is critical for the various private actors if behavioral changes are desired. Policies to restore fiscal balance in public accounts will only increase investment if private agents believe that macroeconomic stability will last. Deregulation will only increase job growth if entrepreneurs believe that the elimination of administrative barriers will not be reversed in short order. Under these circumstances, any institutional reforms widely perceived as externally imposed will not bolster the credibility of - or replacesignals from politicians to voters and, as a result, may not affect public support for reform. By contrast, multilateral or bilateral support in the form of advice on the mechanics of reforming the state that are then implemented by local reformers are more likely to enhance the credibility of these signals.

\section{REFERENCES}

Alesina, A., and A. Drazen, 1991, "Why Are Stabilizations Delayed?" American Economic Review, Vol. 81 (December), pp. 1170-88.

Anderson, C., 1995, Blaming the Government: Citizens and the Economy in Five European Democracies (Armonk, New York: M.E. Sharpe).

Åslund, A., 2000, "Why Has Ukraine Failed to Achieve Economic Growth?" in Economic Reform in Ukraine: The Unfinished Agenda, ed. by Åslund and G. de Ménil (Armonk, New York: M.E. Sharpe).

, P. Boone, and S. Johnson, 2001, "Escaping the Under-Reform Trap," IMF Staff Papers, Vol. 48 (Special Issue), pp. 88-108. 
Beck, N., 2001, "Time-Series-Cross-Section Data: What Have We Learned in the Past Few Years?" Annual Review of Political Science, Vol. 4, pp. 271-93.

Cabanero-Vervosa, C., and P. Mitchell, 2003, “Communicating Economic Reform” (unpublished; Washington: World Bank).

Camdessus, M., 1997, “Camdessus Calls for 'Second Generation' of Reform in Argentina," IMF Survey, Vol. 26 (June 9), pp. 175-76.

Corrales, J., 2002, Presidents without Parties: The Politics of Economic Reform in Argentina and Venezuela in the 1990s (University Park, Pennsylvania: Pennsylvania State University Press).

De Melo, M., C. Denizer, and A. Gelb, 1996, "Patterns of Transition from Plan to Market," World Bank Economic Review, Vol. 10, No. 3, pp. 397-424.

Diaz-Cayeros, A., and B. Magaloni, 2003, "The Politics of Public Spending-Part II. The Programa Nacional de Solidaridad (PRONASOL) in Mexico," background paper to the World Development Report 2004 (Washington: World Bank).

European Bank for Reconstruction and Development (EBRD), 1999, Transition Report 1999: Ten Years of Transition (London: EBRD).

Fearon, J. D., 1999, "Electoral Accountability and the Control of Politicians: Selecting Good Types versus Sanctioning Poor Performance," in Democracy, Accountability, and Representation, Cambridge Studies in the Theory of Democracy No. 2, ed. by A. Przeworski, S. C. Stokes, and B. Manin (New York: Cambridge University Press).

Ferejohn, J., 1986, "Incumbent Performance and Electoral Control," Public Choice, Vol. 50 (January), pp. 5-25.

Gonzalez, M., 2002, "Do Changes in Democracy Affect the Political Budget Cycle? Evidence from Mexico," Review of Development Economics, Vol. 6 (June), pp. 204-24.

Harrington, J.E., Jr., 1993, "Economic Policy, Economic Performance, and Elections," American Economic Review, Vol. 83 (March), pp. 27-42.

Hellman, J. S., 1998, "Winners Take All: The Politics of Partial Reform in Postcommunist Transitions," World Politics, Vol. 50 (January), pp. 203-34.

Henisz, W. J., 2000, “The Institutional Environment for Economic Growth,” Economics and Politics, Vol. 12 (March), pp. 1-32.

Johnson, S., and others, 2000, “Tunneling," American Economic Review, Vol. 90 (May), pp. 22-27.

Kim, B.-Y., and J. Pirttilä, 2003, "The Political Economy of Reforms: Empirical Evidence from Post-Communist Transition in the 1990s," BOFIT Discussion Paper No. 4 (Helsinki: Institute for Economies in Transition, Bank of Finland).

Krueger, A. O., ed., 2000, Economic Policy Reform: The Second Stage (Chicago: University of Chicago Press).

Kuczynski, P.-P., 2003, "Reforming the State," in After the Washington Consensus: Restarting Growth and Reform in Latin America, ed. by Kuczynski and J. Williamson (Washington: Institute for International Economics).

Kurtz, M. J., 2004, "The Dilemmas of Democracy in the Open Economy: Lessons from Latin America," World Politics, Vol. 56 (January), pp. 262-302.

Laban, R., and F. Sturzenegger, 1994, "Distributional Conflict, Financial Adaptation and Delayed Stabilizations," Economics and Politics, Vol. 6, No. 3, pp. 257-76.

Lora, E., and M. Olivera, 2005, "The Electoral Consequences of the Washington Consensus," Economía, Vol. 5 (Spring).

Lora, E., U. Panizza, and M. Quispe-Agnoli, 2004, "Reform Fatigue: Symptoms, Reasons, and Implications," Federal Reserve Bank of Atlanta Economic Review, Vol. 89 (Second Quarter), pp. 1-28. 
Manin, B., 1997, The Principles of Representative Government (New York: Cambridge University Press).

Marshall, M. G., and K. Jaggers, 2001, Polity IV Project: Political Regime Characteristics and Transitions. Available via the Internet: http://www.cidcm.umd.edu/inscr/polity

Mejía Reyes, P., 2003, "Business Cycles and Economic Growth in Latin America: A Survey," Documentos de Investigación No. 71 (Mexico City: Colegio Mexiquense).

Naím, M., 1994, "Latin America: The Second Stage of Reform," Journal of Democracy, Vol. 5 (October), pp. 32-48.

O’Donnell, G. A., 1994, “Delegative Democracy,” Journal of Democracy, Vol. 5 (January), pp. 55-69.

Ortiz, G., 2003, "Latin America and the Washington Consensus: Overcoming Reform Fatigue," Finance and Development, Vol. 40 (September), pp. 14-17.

Plattner, M. F., 1999, "From Liberalism to Liberal Democracy," Journal of Democracy, Vol. 10 (July), pp. 121-34.

Political Risk Services, 2005, International Country Risk Guide (East Syracuse, New York: The PRS Group, Inc.). Available via the Internet: http://www.countrydata.com

Przeworski, A., 1991, Democracy and the Market: Political and Economic Reforms in Eastern Europe and Latin America (New York: Cambridge University Press).

Rodrik, D., 1993, "Positive Economics of Policy Reform," American Economic Review, Papers and Proceedings, Vol. 83 (May), pp. 356-61.

Schady, N. R., 2000, "The Political Economy of Expenditures by the Peruvian Social Fund (FONCODES) 1991-95," American Political Science Review, Vol. 94 (June), pp. 289-304.

Schuknecht, L., 2000, "Fiscal Policy Cycles and Public Expenditure in Developing Countries," Public Choice, Vol. 102 (January), pp. 113-28.

Shleifer, A., and D. Treisman, 2000, Without a Map: Political Tactics and Economic Reform in Russia (Cambridge, Massachusetts: MIT Press).

Stokes, S. C., 2001a, "Economic Reform and Public Opinion in Fujimori's Peru," in Public Support for Market Reforms in New Democracies, Cambridge Studies in Comparative Politics, ed. by Stokes (Cambridge, United Kingdom: Cambridge University Press).

—_ 2001b, Mandates and Democracy: Neoliberalism by Surprise in Latin America (Cambridge, United Kingdom; New York: Cambridge University Press).

Tommasi, M., and A. Velasco, 1996, "Where Are We in the Political Economy of Reform?" Journal of Policy Reform, Vol. 1, No. 2, pp. 187-238.

Tsebelis, G., 2002, Veto Players: How Political Institutions Work (Princeton, New Jersey: Princeton University Press).

Velasco, A., 1997, "A Model of Endogenous Fiscal Deficits and Delayed Fiscal Reforms," NBER Working Paper No. 6336 (Cambridge, Massachusetts: National Bureau of Economic Research).

Warner, A. M., 2001, "Is Economic Reform Popular at the Polls? Russia 1995," Journal of Comparative Economics, Vol. 29 (September), pp. 448-65.

Williamson, J., ed., 1994, The Political Economy of Policy Reform (Washington: Institute for International Economics).

World Bank, 2004a, World Development Report 2005: A Better Investment Climate for Everyone (New York: Oxford University Press).

— 2004b, Unlocking the Employment Potential in the Middle East and North Africa: Toward a New Social Contract (Washington: World Bank). 